\title{
Highly time-resolved chemical characterization of atmospheric submicron particles during 2008 Beijing Olympic Games using an Aerodyne High-Resolution Aerosol Mass Spectrometer
}

\author{
X.-F. Huang ${ }^{1}$, L.-Y. He ${ }^{1}$, M. Hu ${ }^{2}$, M. R. Canagaratna ${ }^{3}$, Y. Sun ${ }^{4}$, Q. Zhang ${ }^{4}$, T. Zhu ${ }^{2}$, L. Xue ${ }^{1}$, L.-W. Zeng ${ }^{1}$, X.-G. Liu ${ }^{2}$, \\ Y.-H. Zhang ${ }^{2}$, J. T. Jayne ${ }^{3}$, N. L. $\mathrm{Ng}^{3}$, and D. R. Worsnop ${ }^{3}$ \\ ${ }^{1}$ Key Laboratory for Urban Habitat Environmental Science and Technology, School of Environment and Energy, Peking \\ University Shenzhen Graduate School, Shenzhen, China \\ ${ }^{2}$ State Key Joint Laboratory of Environmental Simulation and Pollution Control, College of Environmental Sciences and \\ Engineering, Peking University, Beijing, China \\ ${ }^{3}$ Aerodyne Research, Inc. Billerica, MA, USA \\ ${ }^{4}$ Department of Environmental Toxicology, University of California, Davis, CA, USA
}

Received: 5 May 2010 - Published in Atmos. Chem. Phys. Discuss.: 25 May 2010

Revised: 10 September 2010 - Accepted: 21 September 2010 - Published: 24 September 2010

\begin{abstract}
As part of Campaigns of Air Quality Research in Beijing and Surrounding Region-2008 (CAREBeijing2008), an Aerodyne High-Resolution Time-of-Flight Aerosol Mass Spectrometer (HR-ToF-AMS) was deployed in urban Beijing to characterize submicron aerosol particles during the time of 2008 Beijing Olympic Games and Paralympic Games (24 July to 20 September 2008). The campaign mean $\mathrm{PM}_{1}$ mass concentration was $63.1 \pm 39.8 \mu \mathrm{g} \mathrm{m}^{-3}$; the mean composition consisted of organics $(37.9 \%)$, sulfate $(26.7 \%)$, ammonium $(15.9 \%)$, nitrate $(15.8 \%)$, black carbon $(3.1 \%)$, and chloride $(0.87 \%)$. The average size distributions of the species (except BC) were all dominated by an accumulation mode peaking at about $600 \mathrm{~nm}$ in vacuum aerodynamic diameter, and organics was characterized by an additional smaller mode extending below $100 \mathrm{~nm}$. Positive Matrix Factorization (PMF) analysis of the high resolution organic mass spectral dataset differentiated the organic aerosol into four components, i.e., hydrocarbon-like (HOA), cooking-related (COA), and two oxygenated organic aerosols (OOA-1 and OOA-2), which on average accounted for $18.1,24.4,33.7$ and $23.7 \%$ of the total organic mass, respectively. The HOA was identified to be closely associated with primary combustion sources, while the COA mass spectrum and diurnal pattern showed
\end{abstract}

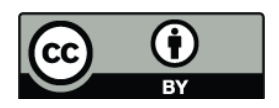

Correspondence to: $\mathrm{L} .-\mathrm{Y} . \mathrm{He}$

(hely@pku.edu.cn) similar characteristics to that measured for cooking emissions. The OOA components correspond to aged secondary organic aerosol. Although the two OOA components have similar elemental $(\mathrm{O} / \mathrm{C}, \mathrm{H} / \mathrm{C})$ compositions, they display differences in mass spectra and time series which appear to correlate with the different source regions sampled during the campaign. Back trajectory clustering analysis indicated that the southerly air flows were associated with the highest $\mathrm{PM}_{1}$ pollution during the campaign. Aerosol particles in southern airmasses were especially rich in inorganic and oxidized organic species. Aerosol particles in northern airmasses contained a large fraction of primary HOA and COA species, probably due to stronger influences from local emissions. The lowest concentration levels for all major species were obtained during the Olympic game days ( 8 to 24 August 2008), possibly due to the effects of both strict emission controls and favorable meteorological conditions.

\section{Introduction}

Due to China's severe levels of air pollution, the air quality during the 2008 Beijing Olympic Games was of global concern. After Beijing's successful application of the host of the 2008 Olympics in 2001, the Beijing government implemented 8 phases of air pollution control measures including improvements in energy structure, reductions in coal burning

Published by Copernicus Publications on behalf of the European Geosciences Union. 
emissions from power plants, regulations on vehicular emission standards, closing and moving high-emitting factories, and enforcement of construction dust control (Beijing Municipal Government, 2008). Meanwhile, the neighboring administrative regions also enacted emission control measures to decrease regional transport of air pollutants to Beijing (Stone, 2008). A series of special temporary measures during which around half of the vehicles $(\sim 1.5$ million) were removed off roads by an odd-even license car ban and some other traffic restriction measures were also executed in Beijing from 20 July to 20 September 2008. It is necessary and important for both scientific understanding and future policy making to evaluate the effectiveness of these drastic control measures on the air quality of Beijing. Several satellite-based studies have recently indicated significant reduction of air pollutants during the 2008 Beijing Olympic Games (Cermak and Knutti, 2009; Mijling et al., 2009; Witte et al., 2009). For example, based on analysis of aerosol optical thickness, Cermak and Knutti (2009) suggested that the magnitude of the aerosol load reduction during the Olympic period was at $10 \sim 15 \%$ compared to that expected without emission reductions. A modeling study also supported significant pollutant reduction during the Olympic period (Wang et al., 2010). More detailed studies, especially analysis of ground-level measurement results with high time resolution, are necessary to interpret in depth variation of surface air quality during the Olympic period.

Particulate matter (PM), especially fine particles, is a crucial air pollutant in urban environments throughout the world. PM is of importance not only due to its direct and indirect radiative forcing effects on climate but also due to its significant adverse health effects. Exposure to high concentrations of submicron particles has been found to lead to more hospitalizations and higher mortality rates (Michaels and Kleinman, 2000; Dockery, 2001; Schwartz et al., 2002). Fine PM is a key air pollutant in Beijing causing frequent low visibility days (Zhang et al., 2010). Over the last decade studies of fine PM in Beijing have revealed that its major chemical components include organic matter (OM), sulfate, nitrate and ammonium; the major sources of the ambient PM include vehicular emissions, coal burning, biomass burning, and secondary formation (e.g., He et al., 2001; Huang et al., 2006; Song et al., 2006; Streets et al., 2007). Previous fine PM chemical characterizations were largely based on off-line filter sampling which provides data of coarse time resolution (e.g., 24 h) and limited size information. Sun et al. (2010) recently reported highly time- and size-resolved fine PM measurement results in Beijing in the summer of 2006 using an Aerodyne quadrupole aerosol mass spectrometer (Q-AMS). Takegawa et al. (2009) also conducted a Q-AMS study on fine PM at a rural site in Beijing ( $\sim 50 \mathrm{~km}$ south of PKU) in the summer of 2006. These in-situ high time resolution measurements provide more information on the variability in fine PM chemistry and microphysics than was available before.
In order to characterize in depth the processes and mechanisms of severe air pollution in Beijing on a regional scale, an international field campaign "Campaigns of Air Quality Research in Beijing and Surrounding Region 2006" (CAREBeijing-2006) was conducted in summer 2006. The publications of CAREBeijing-2006 about aerosol studies indicated that aerosol pollution in Beijing was a regional problem on a scale of up to $1000 \mathrm{~km}$ (Garland et al., 2009; Jung et al., 2009; Matsui et al., 2009) and high PM periods were usually associated with air masses from the south with high concentrations of sulfate, nitrate, and ammonium (Takegawa et al., 2009; van Pinxteren et al., 2009; Yue et al., 2009). However, high time resolution variations of PM were little demonstrated in CAREBeijing-2006. In addition, the complex organic aerosol was not classified into different types to explore their corresponding sources and formation mechanisms in CAREBeijing-2006. "Campaigns of Air Quality Research in Beijing and Surrounding Region-2008 (CAREBeijing-2008)" was a follow-up international field campaign of CAREBeijing-2006 led by Peking University, which aimed at characterizing the air quality during the 2008 Beijing Olympic Games. As part of CAREBeijing-2008, we deployed a High-Resolution Time-of-Flight Aerosol Mass Spectrometer (HR-ToF-AMS) manufactured by Aerodyne Research Inc. (Billerica, MA, USA) in urban Beijing to measure chemical compositions and size distributions of airborne submicron particles with high time resolution. This was the first deployment of an Aerodyne HR-ToF-AMS in China and East Asia. Compared to the Q-AMS, the HR-ToF-AMS provides enhanced sensitivity and chemical resolution particularly for particulate organic species (DeCarlo et al., 2006; Canagaratna et al., 2007). This paper summarizes and analyzes our primary findings in CAREBeijing-2008. A general picture of the fine PM characteristics in Beijing during the unique Olympic period is provided. This paper will provide basic and distinctive information for later studies that aim to comprehensively evaluate the effects of the drastic emission control measures on the air quality in Beijing.

\section{Experimental methods}

\subsection{Sampling site description}

HR-ToF-AMS measurement of airborne fine particles was performed continuously between 24 July and 20 September 2008 on the campus of Peking University (PKU) in the northwest of the urban area of Beijing, which is about $750 \mathrm{~km}^{2}$. As shown in Fig. S1, the campus is about $8 \mathrm{~km}$ to the west of the Beijing Olympic Park with the National Stadium that was also referred to as the Bird's Nest. An Olympic gymnasium for table tennis was also just inside the campus. The monitoring instruments were deployed inside two rooms on the roof of an academic building that was $15 \mathrm{~m}$ high. Except a main road about $150 \mathrm{~m}$ away to the east, no significant 
pollution sources exist near the sampling site. Besides the HR-ToF-AMS, the collocated instruments closely relevant to this study included a Multi-Angle Absorption Photometer (MAAP, Model 5012, Thermo) for fine particle black carbon (BC) mass measurement and a Twin Differential Mobility Particle Sizer (TDMPS) developed by Institute for Tropospheric Research, Germany, for particle number size distribution measurement between 3 and $600 \mathrm{~nm}$.

\subsection{HR-ToF-AMS measurement and data processing}

\subsubsection{HR-ToF-AMS}

The instrumental details of the Aerodyne AMS have been presented in many previous publications and reviewed by Canagaratna et al. (2007). The HR-ToF-AMS uses the same aerosol sampling, sizing, vaporization and ionization schemes as those of the Q-AMS (Jayne et al., 2000; Jimenez et al., 2003) and the Compact-ToF-AMS (Drewnick et al., 2005). A detailed description of HR-ToF-AMS is given in DeCarlo et al. (2006). The main advantage of the HR-ToFAMS over previous versions of AMS is the much improved ability of identification and separation of isobaric ions (especially for $m / z<100$ ) that have the same nominal mass but are slightly different in exact mass due to differences in elemental composition (DeCarlo et al., 2006). As a result, the high resolution mass spectral data can provide valuable information on the elemental composition (e.g., C, H, O and $\mathrm{N}$ ) and thus $\mathrm{OM} / \mathrm{OC}$ ratio of organic aerosol (Aiken et al., 2007, 2008).

It should be noted that all AMS measurements are typically referred to as non-refractory $\mathrm{PM}_{1}\left(\mathrm{NR}-\mathrm{PM}_{1}\right)$ measurements because: (1) particles with vacuum aerodynamic diameters of $1 \mu \mathrm{m}$ particles are transmitted through the inlet at an efficiency of $\sim 30-50 \%$ depending on exact details of the lens assembly and sampling pressure (Jayne et al., 2000; Liu et al., 2006); (2) only non-refractory species, such as ammonium sulfate, ammonium nitrate and OM, can evaporate at the vaporizer temperature (typically $600^{\circ} \mathrm{C}$ for ambient measurements) and then be detected (Canagaratna et al., 2007). Although the presence of significant quantities of refractory particles can be detected via comparison between aerosol size distributions and total mass detected, in order to determine the concentrations of refractory species (such as $\mathrm{BC}$ and crustal materials) simultaneously, other collocated on-line instruments are needed.

\subsubsection{HR-ToF-AMS operation}

A $\mathrm{PM}_{2.5}$ cyclone inlet was supported on the roof of the sampling room to remove coarse particles and introduce air stream into the room through a copper tube with a flow rate of $10 \mathrm{~L} \mathrm{~min}^{-1}$. The HR-ToF-AMS sampled isokinetically from the center of the copper tube at a flow rate of $80 \mathrm{cc} \mathrm{min}^{-1}$. During the campaign, the HR-ToF-AMS operated in a cycle of 5 modes every 10 min, including: 2 min V-mode to obtain the mass concentrations of the non-refractory species; 2 min W-mode to obtain high resolution mass spectral data; 4 min separate PToF (particle time-of-flight) mode to determine size distributions of species under the V-mode; and 2 min Soft-EI mode using a lower EI voltage $(\sim 13 \mathrm{eV})$. The PToF mode was not run under the $\mathrm{W}$-mode because of poor signal-to-noise. The Soft-EI mode data are not included in this paper.

The HR-ToF-AMS was calibrated for inlet flow, ionization efficiency (IE), and particle sizing at the beginning, the middle and the end of the campaign following the standard protocols (Jayne et al., 2000; Jimenez et al., 2003; Drewnick et al., 2005). The calibration of IE used size-selected pure ammonium nitrate particles and the particle size calibration was conducted using mono-disperse polystyrene latex spheres (PSL, density $=1.05 \mathrm{~g} \mathrm{~cm}^{-3}$ ) (Duke Scientific, Palo Alto, California, USA) with nominal diameters of $100-700 \mathrm{~nm}$. The HR-ToF-AMS detection limits of different species were determined by filtered particle-free ambient air and defined as three times the standard deviations of the corresponding species signals (Zhang et al., 2005b; DeCarlo et al., 2006; Sun et al., 2009). The detection limits (for 2 min V-mode averaging) of sulfate, nitrate, ammonium, chloride, and organics during the campaign were calculated to be $0.008,0.004$, $0.026,0.004$, and $0.033 \mu \mathrm{g} \mathrm{m}^{-3}$, respectively. The data obtained between 10:00 a.m. 6 August and 04:00 p.m. $10 \mathrm{Au}-$ gust was eliminated from the data analysis due to problems with water vapor condensation inside the sampling tubing.

\subsubsection{HR-ToF-AMS data processing}

The HR-ToF-AMS provided data with two different resolutions (V-Mode and W-Mode). The lower resolution V-mode data is used to generate unit mass resolution mass spectra from which mass concentrations and size distributions of species are determined. The high mass resolution $\mathrm{W}$ mode is used to separate ion fragments that have the same nominal $\mathrm{m} / \mathrm{z}$ but differing elemental compositions. The $\mathrm{W}$-mode data is used to determine the elemental composition information presented in this paper. The details of general HR-ToF-AMS data analysis are available in DeCarlo et al. (2006) and Aiken et al. (2007). Standard ToF-AMS data analysis software packages (SQUIRREL version 1.49 and PIKA version 1.08) downloaded from the ToF-AMS-Resources webpage (http:// cires.colorado.edu/jimenez-group/ToFAMSResources) were used to generate unit and high resolution mass spectra from the V-mode and W-mode data respectively. For mass concentration calculations, a particle collection efficiency (CE) factor of 0.5 was used to account for the less than unit detection of particles sampled into the AMS. Many previous field studies have shown that $\mathrm{CE}$ values $\sim 0.5$ produce mass concentrations that compare well with collocated measurements (Canagaratna et al., 2007). The relative ionization efficiency (RIE) values used in this study were 1.2 for sulfate, 
1.1 for nitrate, 1.3 for chloride and 1.4 for organics (Jimenez et al., 2003). A RIE value of 4.0-4.7 was used for ammonium based on the measurement of pure $\mathrm{NH}_{4} \mathrm{NO}_{3}$ particles.

Compared with unit mass resolution (UMR) spectra, HR mass spectra can provide better separation of different organic components in PMF analysis (Docherty et al., 2008; Aiken et al., 2009, DeCarlo et al., 2010). Thus, positive matrix factorization (PMF) (Paatero and Tapper, 1994) analysis was conducted on the high resolution (HR) mass spectra $(m / z, 12-150)$ measured with HR-ToF-AMS. In this analysis the observed data is represented as a bilinear factor model $x_{i j}=\Sigma_{p} g_{i p} f_{p j}+e_{i j}$ where $x_{i j}$ are the measured values of $j$ species in $i$ samples. This model is solved with a least squares fitting process to obtain $P$ factors comprised of constant source profiles $\left(f_{j}\right.$, mass spectra for AMS data) and varying contributions over the time period of the dataset $\left(g_{i}\right.$, time series). The fitting process minimizes $\mathrm{Q}$, which is the summed squares of the ratios between the fit residuals and the error estimates of each data point. The residual at each point is $e_{i j}$.

The PMF evaluation tool developed by Ulbrich et al. (2009) was used for the analysis. The data and noise matrices input into the PMF analysis were generated with the default fragmentation waves in PIKA version 1.08. The noise values at each data point were calculated as the sum of electronic and Poisson ion-counting errors for the relevant high resolution ion fragment (Allan et al., 2003; Ulbrich et al., 2009). Noise values of $\mathrm{CO}_{2}^{+}$-related ions at $\mathrm{m} / z 16,17$, 18,28 , and 44 were artificially increased (downweighted) according to the procedure discussed by Ulbrich et al. (2009). Ions were also classified and downweighted according to their signal to noise (SNR) ratios as discussed by Ulbrich et al. (2009). Weak ions $(0.2<\mathrm{SNR}<2)$ were downweighted by a factor of 3 while bad ions $(\mathrm{SNR}<0.2)$ were removed from the analysis (Paatero and Hopke (2003). The average noise value observed for ions during low signal time periods was used as the minimum error value for the error matrix. Elemental analysis of the organic components identified by PMF was carried out with the methods described previously (Aiken et al., 2007, 2008).

The PMF analysis was performed for 1 to 8 factors, but as shown in Table 1 and discussed below the four factor FPEAK $=0$ solution was found to provide the most reasonable solution. A summary of diagnostics and results from the different factor solutions is shown in Table 1. The $Q / Q_{\text {expected values shown in the table represent the ratios }}$ between the actual sum of the squares of the scaled residuals $(Q)$ obtained from the PMF least square fit and the ideal $Q\left(Q_{\text {expected }}\right)$ obtained if the fit residuals at each point were equal to the noise specified for each datapoint. As shown in Table 1, PMF solutions with factor numbers greater than 4 provided no new distinct factors and instead displayed splitting behavior of the existing factors. Thus the four factor solution was chosen as the optimal solution. The fact that the $Q / Q_{\exp }$ values are greater than the ideal value of 1 may be indicative of the fact that the input noise values underestimate the true noise since they do not include errors associated with the high resolution peak fitting process. It is useful to note, however, that in this case, artificially changing noise values to obtain $Q / Q_{\exp }$ values around 1 does not result in any significant changes in factor time trends and mass spectra obtained from the PMF analysis. The sensitivity of the four factor solution to rotation was explored by varying the FPEAK parameter from -3 to 3 . The $Q / Q_{\exp }$ and the factors obtained for the different FPEAKs, particularly in the -1 to 1 range are nearly identical to each other. The sensitivity of the four factor solution to starting values of the fitted parameters was also explored for a range of 25 seed parameter values. Two distinct groups of solutions with slightly different $Q / Q_{\exp }$ values were observed. The factors and mass apportionment of the HOA and COA components are very similar between the two groups of solutions. Between the two different groups of solutions, the total OOA mass remains the same, but the average OOA-1 and OOA-2 mass fractions differ by less than $5 \%$. Based on all of these tests the four factor, FPEAK $=0$, seed $=0$ solution was chosen as the optimal solution for this analysis.

\section{Results and discussion}

\section{1 $\mathrm{PM}_{1}$ chemical compositions and size distributions}

Figure 1 shows time-resolved variation of sulfate, nitrate, chloride, ammonium and organic mass concentrations measured with the HR-ToF-AMS (abbreviated as AMS hereafter) and the BC mass concentration from the aethalometer measurement from 24 July to 20 September 2008 . The corresponding time series of the meteorological parameters at the sampling site are shown in Fig. S2. A very broad range of $\mathrm{PM}_{1}$ mass concentrations between 2.47 and $356 \mu \mathrm{g} \mathrm{m}^{-3}$ was observed; the mean mass concentration was $63.1 \mu \mathrm{g} \mathrm{m}^{-3}$. The variation of the particle volume concentration measured by the collocated TDMPS is also plotted in Fig. 1a for comparison. The particle volume concentration is calculated from the directly-measured particle number size distribution between 3 and $600 \mathrm{~nm}$ in mobility diameter by assuming spherical particles. It is seen that the two measurements trace each other very closely, with a linear correlation coefficient $\left(R^{2}\right)$ of 0.84 .

Figure $1 \mathrm{~b}$ and $\mathrm{c}$ show the time series of species mass concentrations and their percent contributions of the total mass, respectively. All the species varied very largely like the total mass. OM, for example, sometimes reached as high as over $50 \mu \mathrm{g} \mathrm{m}^{-3}$ and as low as less than $1 \mu \mathrm{g} \mathrm{m}^{-3}$. As shown in Fig. 1d, on average $\mathrm{OM}$ was the most abundant $\mathrm{PM}_{1}$ species accounting for $37.9 \%$ of the total mass, followed by sulfate $(26.7 \%)$, ammonium (15.9\%), nitrate $(15.8 \%)$, black carbon $(3.1 \%)$ and chloride $(0.87 \%)$. The statistical values of the $\mathrm{PM}_{1}$ species concentrations during the campaign are 
Table 1. Description of PMF Solutions obtained for this dataset.

\begin{tabular}{|c|c|c|c|c|}
\hline \# Factors & FPEAK & Seed & $Q / Q_{\text {expected }}$ & Solution Description \\
\hline 1 & 0 & 0 & 8.4 & $\begin{array}{l}\text { Too few factors. Large residuals at key } \mathrm{m} / \mathrm{z} \text { 's } \\
\text { and time periods. }\end{array}$ \\
\hline 2 & 0 & 0 & 6 & $\begin{array}{l}\text { Too Few factors. Large Residuals at key } \mathrm{m} / \mathrm{z} \text { 's } \\
\text { and time periods. }\end{array}$ \\
\hline 3 & 0 & 0 & 5.3 & $\begin{array}{l}\text { Too few factors (OOA-, HOA-, and COA- like). } \\
\text { Factor time trends, diurnal cycles, and spectra } \\
\text { appear mixed with each other. }\end{array}$ \\
\hline 4 & $\mathbf{0}$ & $\mathbf{0}$ & 4.887 & $\begin{array}{l}\text { Optimum number of Factors (OOA-1, OOA- } \\
2 \text {, HOA, COA). Distinctive diurnal cycles } \\
\text { for Factors and MS that compare well with } \\
\text { database MS. }\end{array}$ \\
\hline 5 to 8 & 0 & 0 & $4.7-4.3$ & $\begin{array}{l}\text { Splitting, particularly in the OOA factors. } \\
\text { When factors split unrealistic zeros are ob- } \\
\text { served in factor time series. MS with single } \mathrm{m} / z \\
\text { peaks are also observed. Some of the split fac- } \\
\text { tors have time series and MS that appear mixed. }\end{array}$ \\
\hline 4 & 3 to -3 & 0 & $4.92-4.9$ & $\begin{array}{l}\text { In FPEAK range }-1<0<1 \text {, Factor MS and } \\
\text { Time series are nearly identical. For larger } \\
\text { FPEAK range, unreasonable zeros observed in } \\
\text { time series and mass spectra. }\end{array}$ \\
\hline 4 & 0 & $\begin{array}{l}0 \text { to } 250 \\
\text { in steps } \\
\text { of } 10\end{array}$ & $\begin{array}{l}\text { Two sets: } \\
4.887 \text { and } \\
4.898\end{array}$ & $\begin{array}{l}\text { COA and HOA factors trends and MS are nearly } \\
\text { identical for both sets. OOA } 1 / \mathrm{OOA} 2 \text { ratio } \\
\text { varies by } 5 \% \text { between the two sets. }\end{array}$ \\
\hline
\end{tabular}

summarized in Table S1. During the campaign, the measured $\mathrm{NH}_{4}^{+}$matched well the $\mathrm{NH}_{4}^{+}$needed to fully neutralize sulfate, nitrate, and chloride (i.e., $2 \mathrm{SO}_{4}^{2-}+\mathrm{NO}_{3}^{-}+\mathrm{Cl}^{-}$), with a linear correlation coefficient of $R^{2}=0.95$ and a slope of 1.05. Zhang et al. (2007) have summarized previous AMS results from 37 field campaigns in the anthropogenically-influenced Northern Hemisphere mid-latitudes. The average NR-PM mass concentration $\left(61 \mu \mathrm{g} \mathrm{m}^{-3}\right.$, without BC) in this Olympic campaign is much higher than those observed in developed countries (below $20 \mu \mathrm{g} \mathrm{m}^{-3}$ ), but lower than that measured in urban Beijing in 2006 summer $\left(71 \mu \mathrm{g} \mathrm{m}^{-3}\right)$ by Sun et al. (2010).

As the ambient $\mathrm{PM}_{1}$ mass loading during the campaign varied largely, it is interesting to examine the relative contributions of different species at different total mass concentrations. Figure 1e shows that different species exhibit different trends as the total mass concentrations increased. The percent contributions of OM showed a notable decreasing trend from $46 \%$ at $0-10 \mu \mathrm{g} \mathrm{m}^{-3}$ to $30 \%$ at $>220 \mu \mathrm{g} \mathrm{m}^{-3}$ and those of $\mathrm{BC}$ also showed a clear decreasing trend. Conversely, the percent contributions of nitrate showed a notable increasing trend as function of $\mathrm{PM}_{1}$ mass loading, varying from $8.3 \%$ at $0-10 \mu \mathrm{g} \mathrm{m}^{-3}$ to $24 \%$ at $>220 \mathrm{gg} \mathrm{m}^{-3}$. At all mass loading levels, sulfate constituted a relatively stable faction of $\sim 27 \%$. It is also inferred from Fig. 1e that during severe $\mathrm{PM}_{1}$ pollution periods, the contributions of inorganic aerosol (mainly $\left.\left(\mathrm{NH}_{4}\right)_{2} \mathrm{SO}_{4}+\mathrm{NH}_{4} \mathrm{NO}_{3}\right)$ largely exceeded those of carbonaceous aerosol $(\mathrm{OM}+\mathrm{BC})$.

Figure 1f presents the average species size distributions determined by AMS during the campaign. Generally, all the species showed an apparent accumulation mode peaking at a large size of $\sim 600 \mathrm{~nm}$, which is indicative of aged regional aerosol (Allan et al., 2003; Alfarra et al., 2004; Zhang et al., 2005c). The signal at vacuum aerodynamic diameters greater than $1000 \mathrm{~nm}$ likely reflects the reduced but non-zero transmission of the lens at these sizes as well tailing due to delayed single particle vaporization events (Cross et al., 2009). The very similar size distribution patterns of sulfate, nitrate and ammonium suggest they were likely internally mixed and came from similar gas-to-particle processes. The size distribution of $\mathrm{OM}$ was much broader at smaller sizes, and the contribution of $\mathrm{OM}$ to the total mass was more and more 

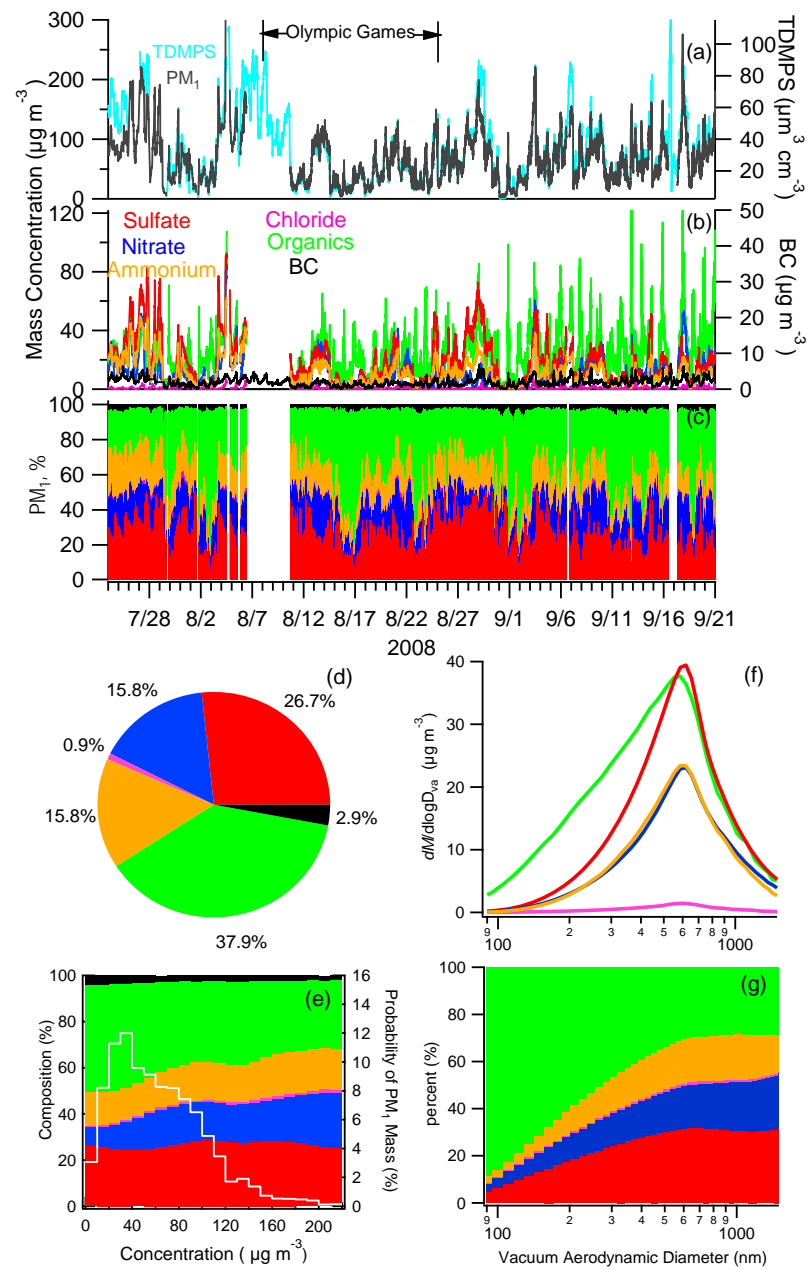

Fig. 1. Chemical compositions and size distributions of $\mathrm{PM}_{1}$ during the campaign: time series of (a) the $\mathrm{PM}_{1}$ mass concentrations by AMS species+BC and TDMPS; (b) the AMS species and BC; (c) the percent chemical composition; (d) the average chemical composition; (e) the variation of the percent composition with the $\mathrm{PM}_{1}$ mass concentration; (f) the average size distributions of AMS species; (g) the variation of the percent composition with size.

important with the size decreasing, as shown in Fig. 1g. In the ultrafine mode $(<100 \mathrm{~nm})$, OM contributed as high as $86 \%$ of the total mass. The prominence of OM at smaller sizes is reasonable considering the fresh emission of carbonaceous particles from vehicles in urban environment, which typically has a mass weighted size distribution peaking at a vacuum aerodynamic diameter of $\sim 100 \mathrm{~nm}$ (Canagaratna et al., 2004). The enrichment of OM at smaller sizes was also observed in other urban AMS measurements (e.g., Allan et al., 2003; Alfarra et al., 2004; Zhang et al., 2005c; Aiken et al., 2009).

\subsection{Diurnal variation of $\mathrm{PM}_{1}$ species}

Figure 2 presents the diurnal variation patterns of different $\mathrm{PM}_{1}$ species in the form of box plot. The diurnal trends of aerosol species are complex outcomes of several factors including: (1) more favorable dispersion conditions in the daytime like higher planetary boundary layer (PBL) and wind speeds; (2) more active photochemical production of secondary species in the daytime; (3) gas-particle partitioning of semi-volatile species as a function of ambient temperature and relative humidity; and (4) daily regular local primary emissions like rush hour traffic and cooking. Due to the combined influences of these factors, different species presented different diurnal trends in this campaign. On average, sulfate and ammonium presented a relatively stable concentration level within the $24 \mathrm{~h}$, except for a slight continuous increase in the afternoon. The lowest concentrations of nitrate were observed in the afternoon, suggesting that the amount of its secondary production could not overwhelm its evaporation into gaseous $\mathrm{HNO}_{3}$ and the dilution by the higher PBL in the afternoon. Particulate nitrate has been observed to form photochemically after sunrise and partially evaporates in the afternoon (Zhang et al., 2005b; Salcedo et al., 2006; Hennigan et al., 2008; Zheng et al., 2008). Chloride, in the form of semi-volatile $\mathrm{NH}_{4} \mathrm{Cl}$, shows a trend that is inversely correlated with ambient temperature, which typically reached the highest at 02:00 03:00 p.m. and the lowest at 05:00 07:00 a.m. during the campaign. Organic matter has both large primary and secondary sources, and is also influenced by its semi-volatile components. The observed diurnal variation of $\mathrm{OM}$ was characterized by a big peak in the evening and another small peak at noon. Identification and description of the time trends of different organic components will be discussed in the next section.

BC, a tracer species for combustion sources, showed the highest values in the late evening and the lowest values in the afternoon, which is generally similar to the observations of elemental carbon diurnal patterns in Beijing in summer 2006 (Han et al., 2009; Lin et al., 2009). The lower concentrations in the afternoon are a result of the high daytime PBL as well as reduced heavy duty diesel truck emissions during the day. Due to Beijing traffic regulations heavy duty diesel truck traffic is several times higher at night than during the day; Han et al. (2009) have linked this increase in nighttime heavy duty diesel traffic to late evening peaks in $\mathrm{BC}$ concentrations. During the Olympic period, higher emissions of heavy duty vehicles during nighttime were also observed (Beijing Municipal Government, 2008). A clear morning $\mathrm{BC}$ peak was also observed in this campaign and could be mainly attributed to the morning rush hour traffic including the passenger flow before the games. It should be noted that the diurnal variation of $\mathrm{BC}$ mass concentrations during this Olympic campaign (late evening highest/afternoon lowest $=1.8$ ) was much smaller than that observed in summer 2006 (late evening highest/afternoon lowest $>4$ ), implying a 

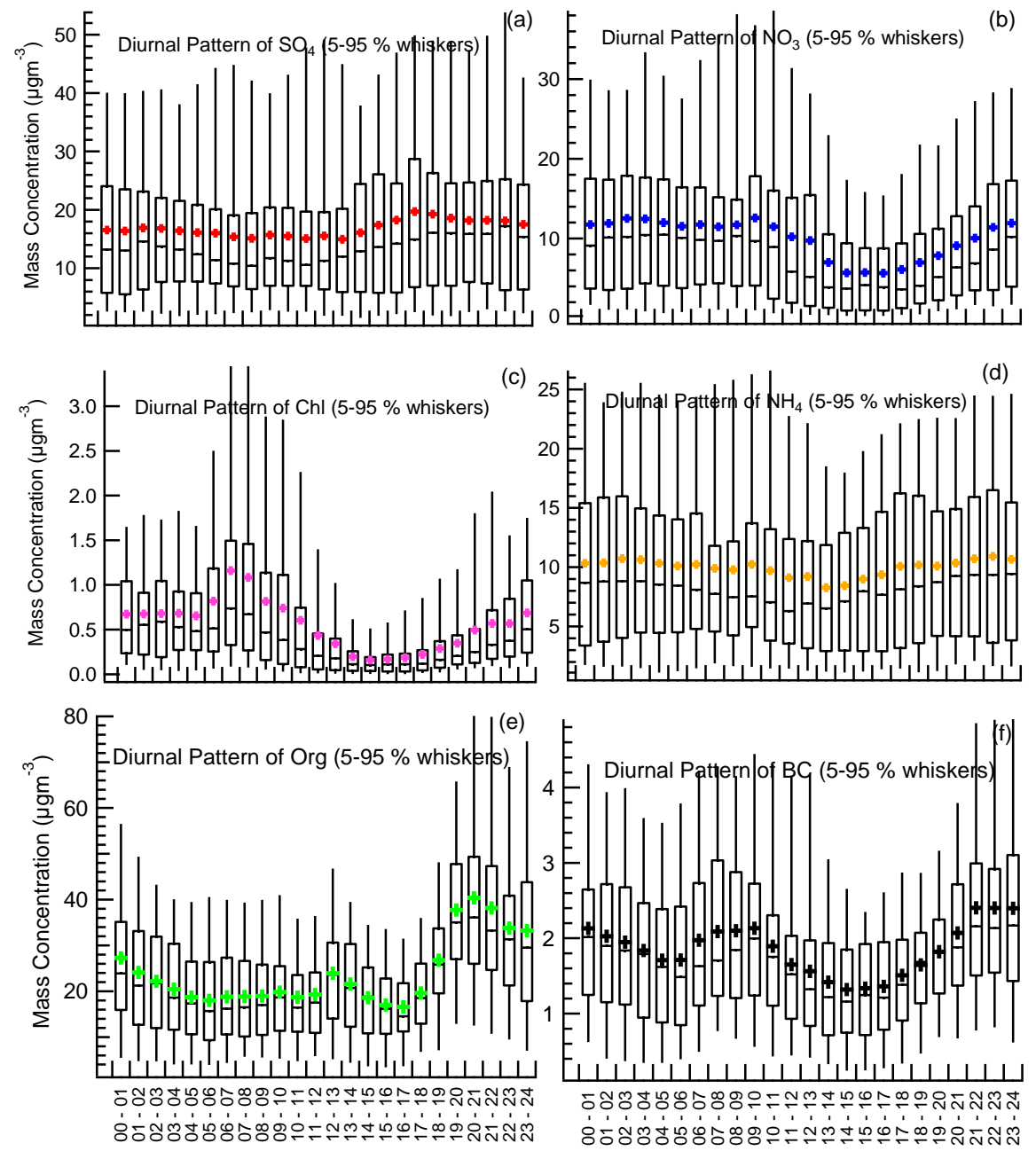

Fig. 2. Diurnal variation box plots of $\mathrm{PM}_{1}$ species. The upper and lower boundaries of boxes indicate the 75 th and 25 th percentiles; the line within the box marks the median; the whiskers above and below boxes indicate the 90th and 10th percentiles; and cross symbols represent the means.

notable traffic control effect of the odd-even license car ban and other traffic restriction measures during the Olympic period.

\subsection{Differentiation of organic components by PMF}

PMF analysis of the high resolution mass spectra of organics measured throughout the campaign identified four organic components including a hydrocarbon-like (HOA), a cookingrelated (COA), and two oxygenated (OOA-1 and OOA-2) organic aerosol components. The components were examined for their MS signatures, and then for their correlation with tracers, diurnal variations and other characteristics (Zhang et al., 2005c; Ulbrich et al., 2009). Figure 3 shows the MS profiles of the four components, and Fig. 4a-d show their time series during the campaign. On average, the HOA, COA, OOA- 1 and OOA-2 accounted for 18.1, 24.4, 33.7 and $23.7 \%$ of the total organic mass, respectively, as shown in Fig. 4e.
The HOA and COA components, which had low O/C ratios of 0.17 and 0.11 were primarily dominated the ion series of $\mathrm{C}_{n} \mathrm{H}_{2 n+1}^{+}$and $\mathrm{C}_{n} \mathrm{H}_{2 n-1}^{+}$, which are characteristics of organic aerosol MS from primary emission sources (Canagaratna et al., 2004; Mohr et al., 2009) respectively. The HOA concentrations correlated well with those of $\mathrm{BC}$ $\left(R^{2}=0.45\right)$ and their diurnal patterns were quite similar (Fig. $4 \mathrm{f}$ and Fig. 2), indicating the HOA was also from combustion processes. The HOA component has been extensively identified in previous factor analyses of AMS ambient aerosol datasets and mainly attributed to primary combustion sources (Zhang et al., 2007; Lanz et al., 2007; Ulbrich et al., 2009). The $\mathrm{O} / \mathrm{C}$ ratio $(=0.17)$ of the HOA identified here is significantly higher than $0.03-0.04$ measured for direct emissions from diesel and gasoline vehicles (Mohr et al., 2009). However, a similar elevated $\mathrm{O} / \mathrm{C}$ ratio of 0.18 was also observed for the HOA component extracted by PMF analysis of an urban AMS dataset from Mexico City (Aiken et al., 


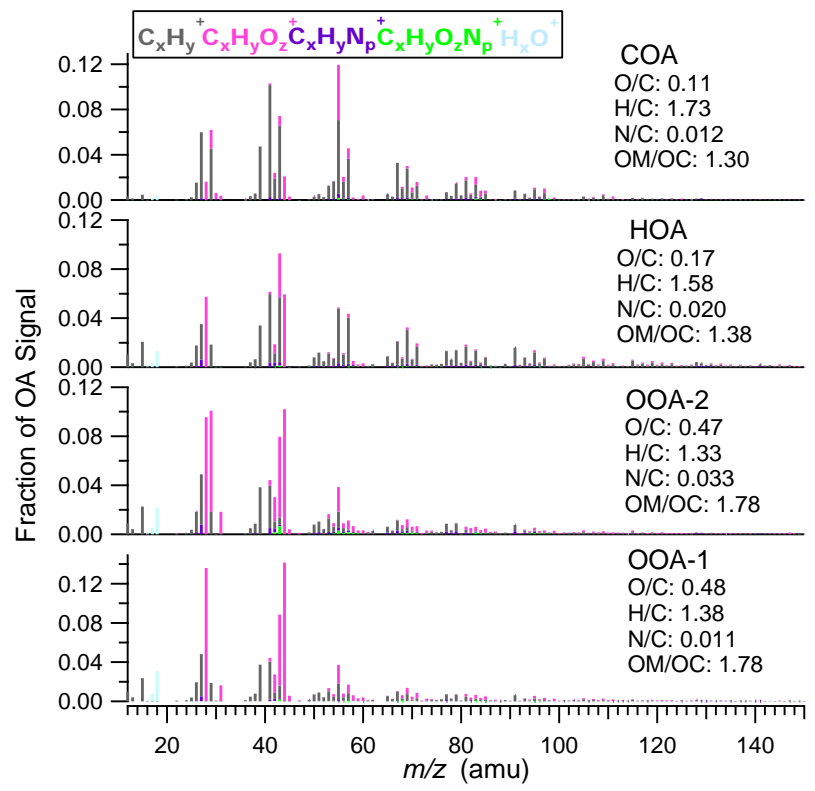

Fig. 3. The MS profiles of the four OA components of this study identified by PMF.

2009). It is useful to note that biomass burning, a known primary source with a relatively higher $\mathrm{O} / \mathrm{C}$ ratio $(0.3-0.4)$, seemed not to have contributed significantly because there was negligible $\mathrm{m} / \mathrm{z} 60$, a tracer ion for biomass burningemitted aerosols, in the HOA MS (Alfarra et al., 2007; Aiken et al., 2009).

The COA MS extracted in this study has very similar O/C ratio $(=0.11)$ to those measured for chicken and hamburger cooking (0.11-0.14). The MS of the COA is characterized by most prominent ions of $\mathrm{m} / \mathrm{z} 41$ (mainly $\mathrm{C}_{3} \mathrm{H}_{5}^{+}$) and $\mathrm{m} / \mathrm{z}$ 55 (mainly $\mathrm{C}_{4} \mathrm{H}_{7}^{+}$), which indicates large presence of unsaturated organic compounds (e.g., unsaturated fatty acids) and is well consistent with the MS characteristics measured for primary Chinese cooking emissions (He et al., 2010). For more details about the comparison between the MS of the COA and primary Chinese cooking emissions, please refer to $\mathrm{He}$ et al. (2010). A clear and unique diurnal pattern of COA provides another piece of strong evidence for it being cookingrelated: it presented a small peak at noon and a large peak in the evening, according with the lunch and dinner times of the local residents. The COA did not significantly correlate with $\mathrm{BC}\left(R^{2}=0.10\right)$, consistent with previous measurements that carbonaceous aerosols emitted from Chinese cooking are almost purely organic (He et al., 2004; Zhao et al., 2007). Due to the unique Chinese cooking habits and culture, cooking emissions have been regarded as one of the major organic aerosol sources in Chinese unban environments (He et al., 2004; Zhao et al., 2007). Therefore, it was a consequential result to identify a notable cooking-related organic aerosol component in this study. Mohr et al. (2009) pointed out that
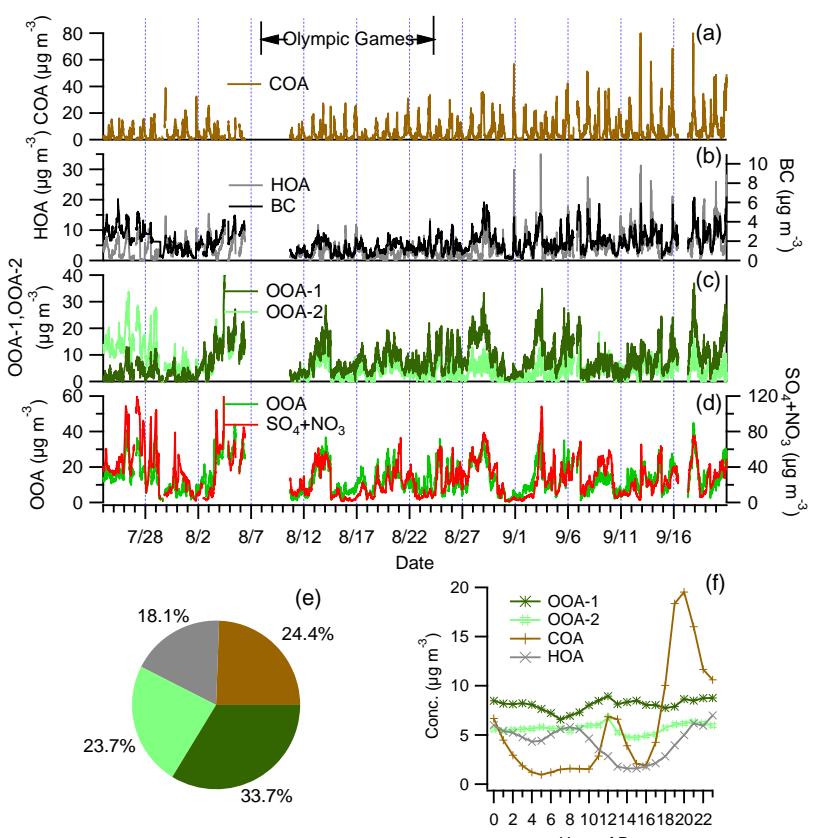

Hour of Day

Fig. 4. Time series of (a-d) the OA components and other relevant species, (e) the average OA component contributions, and (f) the diurnal variations.

motor vehicles, plastic burning and meat cooking are very likely to be retrieved as a single component in PMF analysis of AMS data due to the similarity of their UMR spectra, but utilization of HR-ToF-AMS may allow better separation of meat cooking from the other primary sources due to the larger differences in HR spectra. Our PMF results are consistent with this hypothesis.

The MS of the two OOA components were both characterized by prominent $\mathrm{C}_{\mathrm{x}} \mathrm{H}_{\mathrm{y}} \mathrm{O}_{\mathrm{z}}$ fragments, especially $\mathrm{CO}_{2}^{+}$ $(\mathrm{m} / z 44)$, suggesting large presence of oxidized organic compounds. OOAs have been extensively identified in previous AMS studies and shown to be a good surrogate of SOA (Zhang et al., 2005c, 2007; Jimenez et al., 2009; Ng et al., 2010; Sun et al., 2010). Two types of OOAs with different $\mathrm{O} / \mathrm{C}$ ratios and volatilities have been observed in many ambient datasets: the OOA with higher $\mathrm{O} / \mathrm{C}$, which is more oxidized and aged, is referred to as low-volatility OOA (LVOOA); the OOA with lower $\mathrm{O} / \mathrm{C}$, which is less oxidized and fresher, is referred to as semi-volatile OOA (Jimenez et al., 2009; Ng et al., 2010). OOA time trends typically correlate well with those of inorganic secondary species with SV-OOA correlating best with semi-volatile aerosol nitrate and LV-OOA correlating better with the less volatile sulfate (Docherty et al., 2008; Huffman et al., 2009; Jimenez et al., 2009; Ng et al., 2010). Ng et al. (2010) recently summarized the $\mathrm{O} / \mathrm{C}$ ratio ranges of OOAs based on global AMS measurements and indicated a wide range of $\mathrm{O} / \mathrm{C}$ for both $\mathrm{LV}$ OOA $(0.73 \pm 0.14)$ and SV-OOA $(0.35 \pm 0.14)$ components, 
reflecting the fact that there is a continuum of OOA properties in ambient aerosol.

While the OOA components extracted during this campaign have different mass spectra, they have similar $\mathrm{O} / \mathrm{C}$ ratios of 0.48 (OOA-1) and 0.47 (OOA-2), which lie in the SV-OOA to LV-OOA overlap region observed for northern hemispheric O/Cs (Jimenez et al., 2009; Ng et al., 2010). Moreover, both OOAs correlate best with aerosol nitrate and have poorer correlations with aerosol sulfate (Fig. S3). This indicates that the mass spectral and temporal differences in the OOA observed in this campaign are not a result of large differences in $\mathrm{O} / \mathrm{C}$ and/or volatility. The two types of OOAs observed in this campaign appear to correlate instead with meteorological changes at the site and most likely correspond to differing background OOA compositions from different source regions. As shown in Fig. 5 in Sect. 3.4, the OOA-2/OOA-1 ratio was higher in air masses from the south $(0.77 \sim 0.94)$ than in air masses from the north $(0.39 \sim 0.75)$. Thus, in this paper we refer to the two types of OOA as OOA-1 and OOA-2 instead of LV-OOA and SV-OOA respectively. In general, OOA-2 correlated better with sulfate and nitrate than OOA-1, indicating that the source regions of OOA-2 were more similar to those of $\mathrm{SO}_{2}$ and $\mathrm{NO}_{\mathrm{x}}$ emissions, consistent with the back trajectory analysis in Sect. 3.4. When considering OOA-1 and OOA-2 together, the sum of them showed high correlation with the sum of sulfate and nitrate $\left(R^{2}=0.68\right.$, in Fig. S3), but no correlation with the sum of HOA and COA $\left(R^{2}=0.04\right.$, in Fig. S3), confirming their secondary nature and representativeness of SOA. Similarly, in a Q-AMS study conducted in urban Beijing in summer 2006, Sun et al. (2010) also observed tight correlations $\left(R^{2}=0.69\right)$ between total OOA and total secondary inorganic species $\left(\mathrm{SO}_{4}^{2-}+\mathrm{NO}_{3}^{-}\right)$. The average $(\mathrm{OOA}-1+\mathrm{OOA}-$ $2) /\left(\mathrm{SO}_{4}^{2-}+\mathrm{NO}_{3}^{-}\right)$ratios are almost the same $(\approx 0.42)$ between the two studies too. However, tighter correlations between OOA- 1 and sulfate and between OOA-2 and nitrate were observed in summer 2006 (Sun et al., 2010).

\subsection{Back trajectory clustering analysis}

To explore the influence of regional transport on $\mathrm{PM}_{1}$ loading and composition during the Olympic campaign, back trajectory (BT) analysis was performed using the HYbrid Single Particle Lagrangian Integrated Trajectory (HYSPLIT4) model developed by NOAA/ARL (Draxler and Rolph, 2003). Firstly, 48-h back trajectories staring at $500 \mathrm{~m}$ above ground level in Beijing $\left(39.99^{\circ}, 116.31^{\circ}\right)$ were calculated every $6 \mathrm{~h}$ (at 0, 6, 12 and 18:00 LT, local time) during the entire campaign; the trajectories were then clustered according to their similarity in spatial distribution using the HYSPLIT4 software. The clustering principles and processes are described in the user's guide of the software (Draxler et al., 2009). Five-cluster solution was adopted because of its small total spatial variance, and the mean BT of each cluster was exhibited in Fig. 5. The southerly BT group, cluster S, was

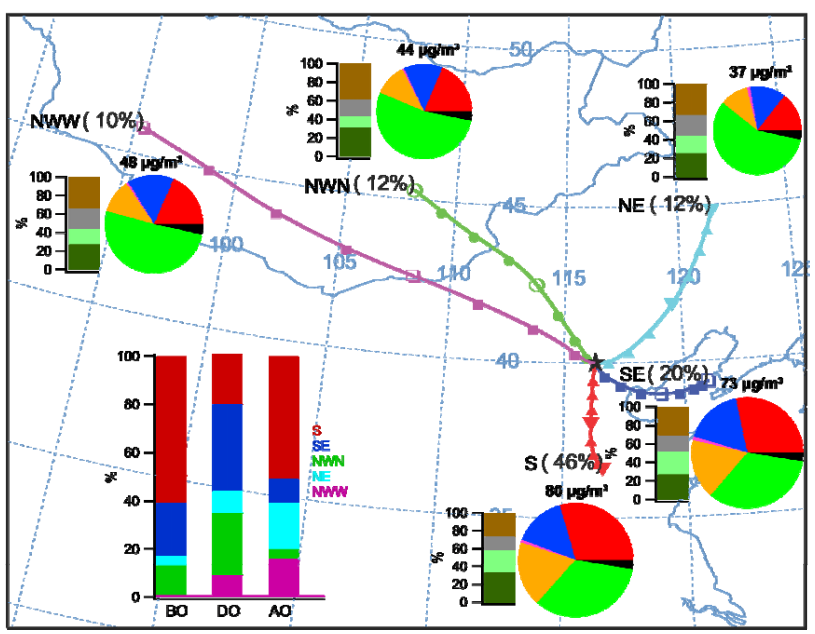

Fig. 5. The back trajectory clusters associated the corresponding average $\mathrm{PM}_{1}$ compositions during the campaign. The inserted bar graph shows the directional variation of BTs before the Olympics (BO, 23 July-7 August), during the Olympics (DO, 8-24 August) and after the Olympics (AO, 25 August-20 September).

found to be the most frequent one, accounting for $45.7 \%$ of all BTs, which is an expected result of the typical summer meteorology in Beijing. Clusters SE, NE, NWN, and NWW accounted for 20.1, 12.3, 11.9 and $10.0 \%$ of all BTs, respectively.

As a second step, the $\mathrm{PM}_{1}$ chemical compositions corresponding to the BTs in each cluster were averaged, which is also exhibited in Fig. 5. Clusters $\mathrm{S}$ represents the most polluted air mass origin with a mean $\mathrm{PM}_{1}$ mass concentration of $80.1 \mu \mathrm{g} \mathrm{m}^{-3}$ followed by clusters SE $\left(72.8 \mu \mathrm{g} \mathrm{m}^{-3}\right)$, NWW $\left(48.2 \mu \mathrm{g} \mathrm{m}^{-3}\right)$, NWN $\left(44.2 \mu \mathrm{g} \mathrm{m}^{-3}\right)$ and NE $\left(37.0 \mu \mathrm{g} \mathrm{m}^{-3}\right)$ in sequence. This finding is generally consistent with some previous studies that also revealed severe aerosol pollution in southerly air flow in summer Beijing (Streets et al., 2007; Jia et al., 2008; Zhao et al., 2009; Sun et al., 2010). Emission inventory and satellite studies also pointed out high emissions to the south of Beijing but much less emissions to the north (Cao et al., 2006; Guo et al., 2009; Zhang et al., 2009). Sun et al. (2010) performed similar back trajectory analysis for their Q-AMS measurement results in Beijing in summer 2006 and observed a mean NR-PM 1 mass concentration of $114 \mu \mathrm{g} \mathrm{m}^{-3}$ for the southerly BTs. In comparison, the NR$\mathrm{PM}_{1}$ pollution level $\left(78.5 \mu \mathrm{g} \mathrm{m}^{-3}\right.$, without $\left.\mathrm{BC}\right)$ associated with the southerly BTs in the Olympic campaign was largely decreased by $31 \%$, suggesting possible pollution control effects during the Olympic period. However, this difference could also be influenced to some extent by the agreement of the different AMS instruments used.

Different $\mathrm{PM}_{1}$ species showed different BT-dependence characteristics and can be roughly classified into two types: $\mathrm{BC}, \mathrm{HOA}, \mathrm{COA}$ and OOA-1 accounted for larger fractions of the observed aerosol mass in northerly air masses; in 
contrast, sulfate, nitrate, chloride, ammonium and OOA-2 accounted for more of the mass in the high concentration air masses associated with clusters $\mathrm{S}$ and $\mathrm{SE}$. This suggests that the high concentration $\mathrm{PM}_{1}$ associated with southerly air masses are dominated by secondary regional aerosol constituents while the northerly air masses have a larger contribution from local, primary aerosol emissions. Similar conclusions were made based on a Q-AMS study in Beijing in summer 2006 (Sun et al., 2010). However, the statistical significance of this BT analysis here may be significantly higher due to the much longer measurement period.

\subsection{Comparison of $\mathrm{PM}_{1}$ characteristics in different periods}

To examine in more detail the $\mathrm{PM}_{1}$ pollution during the Olympic game days, the entire campaign was divided into three periods including before the Olympics (BO, 23 July-7 August), during the Olympics (DO, 8-24 August) and after the Olympics (AO, 25 August-20 September). The average $\mathrm{PM}_{1}$ compositions in the three periods are compared in Fig. 6. The mean $\mathrm{PM}_{1}$ mass concentration in $\mathrm{DO}$ was $47.0 \mu \mathrm{g} \mathrm{m}^{-3}$, much lower than in $\mathrm{BO}\left(87.5 \mu \mathrm{g} \mathrm{m}^{-3}\right)$ and $\mathrm{AO}$ $\left(66.8 \mu \mathrm{g} \mathrm{m}^{-3}\right)$. All the $\mathrm{PM}_{1}$ components except COA, OOA1 and OOA-2 had the lowest concentration levels in DO among the three periods, as shown in Fig. 6. The large bulk decease of $\mathrm{PM}_{1}$ loading in DO may have both meteorological and emission control influence. Firstly, although the entire campaign was within the officially announced emission control period (20 July-20 September), the control measures were inferred to be executed more strictly in DO. Secondly, the meteorology of the DO period was characterized by a lower fraction of cluster $\mathrm{S}$ (the one associated with highest $\mathrm{PM}_{1}$ loading; Fig. 5) and a higher fraction of cluster NWN (a cleaner one; Fig. 5), as compared in Sect. 3.4. To quantify the relative importance of the responsible factors leading to the lower $\mathrm{PM}_{1}$ loading in $\mathrm{DO}$, detailed modeling work is needed, which is beyond the scope of this study.

COA showed the highest concentrations in AO. Due to Olympic security, the actual population of Beijing was largely decreased in $\mathrm{BO}$ and $\mathrm{DO}$ and this may have led to less daily food consumption/cooking in the immediate Beijing area. Lower cooking activities in the DO period could also be assumed judging from occupancies in common restaurants during that time. After the closing ceremony of the Olympics, however, the floating population such as migrant workers began to return to Beijing and cooking emissions went back to normal. Although the total OOA presented a pattern with the lowest concentrations in DO, it was a combined result of the different trends of OOA-1 and OOA-2: OOA-1 showed an increasing trend from $\mathrm{BO}$, DO to $\mathrm{AO}$, while OOA-2 showed the highest concentrations in $\mathrm{BO}$ and much lower concentrations in DO and AO.
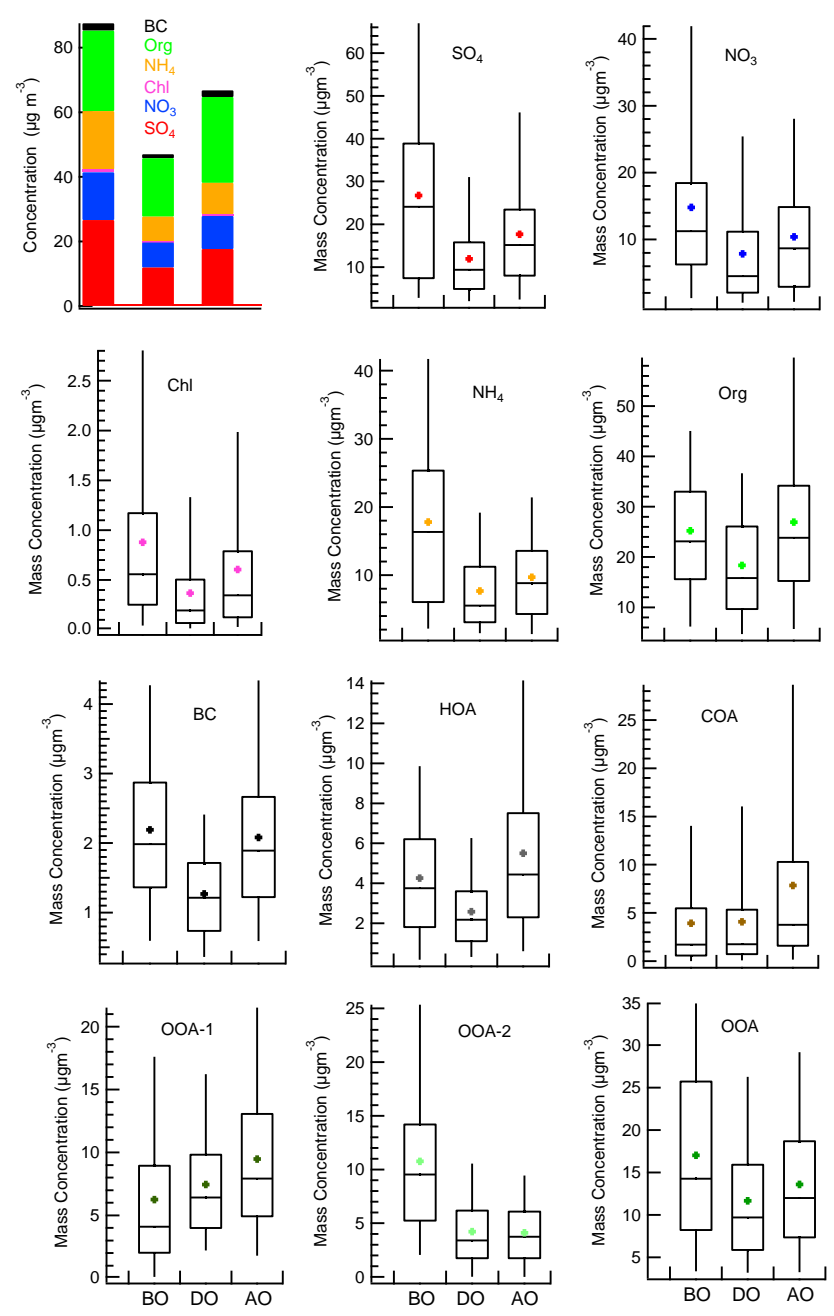

Fig. 6. The comparison of $\mathrm{PM}_{1}$ compositions before the Olympics (BO, 23 July-7 August), during the Olympics (DO, 8-24 August) and after the Olympics (AO, 25 August-10 September).

\section{Conclusions}

As part of the CAREBeijing-2008 campaign, a HR-ToFAMS was deployed in urban Beijing to characterize submicron particles during the 2008 Beijing Olympic Games (24 July to 20 September 2008). PM $_{1}$ mass concentrations, measured with $10 \mathrm{~min}$ time resolution, varied largely between 2.47 and $356 \mu \mathrm{g} \mathrm{m}^{-3}$ during the campaign, with an average of $63.1 \mu \mathrm{g} \mathrm{m}^{-3}$. Organic species were the most abundant $\mathrm{PM}_{1}$ components accounting for $37.9 \%$ of the total mass. The other $\mathrm{PM}_{1}$ components include sulfate (26.7\%), ammonium $(15.9 \%)$, nitrate $(15.8 \%)$, black carbon $(3.1 \%)$ and chloride $(0.87 \%)$ in sequence. The percent contribution of nitrate and ammonium increased significantly with total $\mathrm{PM}_{1}$ loading. The percent contribution of organics, on the other hand, decreased with total $\mathrm{PM}_{1}$ loading. The average size distributions of the species (excluding BC) were all dominated by an 
accumulation mode peaking at $\sim 600 \mathrm{~nm}$ in $D_{\text {va }}$, and moreover, organics was characterized by an additional smaller mode extending below $100 \mathrm{~nm}$ due to combustion sources. Positive Matrix Factorization (PMF) analysis of the high resolution organic mass spectral dataset identified four organic components (HOA, COA, OOA-1 and OOA-2), which on average accounted for $18.1,24.4,33.7$ and $23.7 \%$ of the total organic mass, respectively. The HOA was identified to be closely associated with primary combustion sources as in previous studies. The COA mass spectrum and diurnal pattern showed similar characteristics to that measured for cooking emissions. The elemental compositions of the OOA-1 and OOA-2 are similar and these two types of OOA appear to reflect the different source regions sampled throughout the campaign. Air masses from the south contained aerosol with a dominant fraction of secondary inorganic and organic material. Aerosol observed in air masses from the north was dominated by organic material and most of the organic mass was accounted for by primary HOA and COA sources. The $\mathrm{PM}_{1}$ mass concentrations of all species decreased during the Olympic game days (8 to 24 August 2008), likely due to both strict emission controls and favorable meteorological conditions.

\section{Supplementary material related to this article is available online at: http://www.atmos-chem-phys.net/10/8933/2010/ acp-10-8933-2010-supplement.pdf.}

Acknowledgements. This work was supported by the CAREBeijing-2008 project, the National Natural Science Foundation of China $(20777001,20977001)$, the US National Science Foundation (grant ATM-0840673), and the US Department of Energy (grant DE-FG02-08ER64627). The authors gratefully acknowledge Donna Sueper of University of Colorado at Boulder for her help with data processing and the NOAA Air Resources laboratory (ARL) for the provision of the HYSPLIT transport and dispersion model and READY website used in this publication.

Edited by: D. Parrish

\section{References}

Aiken, A. C., DeCarlo, P. F., and Jimenez, J. L.: Elemental analysis of organic species with electron ionization high-resolution mass spectrometry, Anal. Chem., 79, 8350-8358, 2007.

Aiken, A. C., Decarlo, P. F., Kroll, J. H., et al.: O/C and OM/OC ratios of primary, secondary, and ambient organic aerosols with high-resolution time-of-flight aerosol mass spectrometry, Environ. Sci. Technol., 42, 4478-4485, 2008.

Aiken, A. C., Salcedo, D., Cubison, M. J., Huffman, J. A., DeCarlo, P. F., Ulbrich, I. M., Docherty, K. S., Sueper, D., Kimmel, J. R., Worsnop, D. R., Trimborn, A., Northway, M., Stone, E. A., Schauer, J. J., Volkamer, R. M., Fortner, E., de Foy, B., Wang, J., Laskin, A., Shutthanandan, V., Zheng, J., Zhang, R., Gaffney, J., Marley, N. A., Paredes-Miranda, G., Arnott, W. P., Molina, L. T.,
Sosa, G., and Jimenez, J. L.: Mexico City aerosol analysis during MILAGRO using high resolution aerosol mass spectrometry at the urban supersite (T0) - Part 1: Fine particle composition and organic source apportionment, Atmos. Chem. Phys., 9, 66336653, doi:10.5194/acp-9-6633-2009, 2009.

Alfarra, M. R., Coe, H., Allan, J. D., et al.: Characterization of urban and rural organic particulate in the lower Fraser valley using two aerodyne aerosol mass spectrometers, Atmos. Environ., 38, 5745-5758, 2004.

Alfarra, M. R., Prevot, A. S. H., Szidat, S., et al.: Identification of the mass spectral signature of organic aerosols from wood burning emissions, Environ. Sci. Technol., 41, 5770-5777, 2007.

Allan, J. D., Alfarra,M. R., Bower, K. N., et al.: Quantitative sampling using an Aerodyne AerosolMass Spectrometer. Part 2: Measurements of fine particulate chemical composition in two UK Cities, J. Geophys. Res.-Atmos., 108, 4091, doi:10.1029/2002JD002359, 2003.

Allan, J. D., Delia, A. E., Coe, H., et al.: A generalised method for the extraction of chemically resolved mass spectra from aerodyne aerosol mass spectrometer data, J. Aerosol Sci., 35, 909-922, 2004.

Beijing Municipal Government, Announcement of local measures of air quality assurance during the 2008 Beijing Olympic and Paralympic Games, online available at: http://www.beijing.gov. cn (last access: August 2009), 2008 (in Chinese).

Canagaratna, M. R., Jayne, J. T., Ghertner, D. A., et al.: Chase studies of particulate emissions from in-use New York city vehicles, Aerosol. Sci. Tech., 38, 555-573, 2004.

Canagaratna, M. R., Jayne, J. T., Jimenez, J. L., et al.: Chemical and microphysical characterization of ambient aerosols with the aerodyne aerosol mass spectrometer, Mass Spectrom. Rev., 26, 185-222, 2007.

Cao, G. L., Zhang, X. Y., and Zheng, F. C.: Inventory of black carbon and organic carbon emissions from China, Atmos. Environ., 40, 6516-6527, 2006.

Cermak, J. and Knutti, R.: Beijing Olympics as an aerosol field experiment, Geophys. Res. Lett., 36, L10806, doi:10.1029/2009GL038572, 2009.

Cross, E. S., Onasch, T. B., Canagaratna, M., Jayne, J. T., Kimmel, J., Yu, X.-Y., Alexander, M. L., Worsnop, D. R., and Davidovits, P.: Single particle characterization using a light scattering module coupled to a time-of-flight aerosol mass spectrometer, Atmos. Chem. Phys., 9, 7769-7793, doi:10.5194/acp-9-7769-2009, 2009.

DeCarlo, P. F., Kimmel, J. R., Trimborn, A., et al.: FieldDeployable, High-Resolution Time-of-Flight Aerosol Mass Spectrometer, Anal. Chem., 78, 8281-8289, 2006.

DeCarlo, P. F., Ulbrich, I. M., Crounse, J., de Foy, B., Dunlea, E. J., Aiken, A. C., Knapp, D., Weinheimer, A. J., Campos, T., Wennberg, P. O., and Jimenez, J. L.: Investigation of the sources and processing of organic aerosol over the Central Mexican Plateau from aircraft measurements during MILAGRO, Atmos. Chem. Phys., 10, 5257-5280, doi:10.5194/acp-10-52572010, 2010.

Docherty, K. S., Stone, E. A., Ulbrich, I. M., et al.: Apportionment of Primary and Secondary Organic Aerosols in Southern California during the 2005 Study of Organic Aerosols in Riverside (SOAR-1), Environ. Sci. Technol., 42, 7655-7662, 2008.

Dockery, D. W.: Epidemiologic evidence of cardiovascular effects 
of particulate air pollution, Environ. Health Persp., 109, 483486, 2001.

Draxler, R. R. and Rolph, G. D.: HYSPLIT (HYbrid Single-Particle Lagrangian Integrated Trajectory) Model access via NOAA ARL READY Website (http://www.arl.noaa.gov/ready/hysplit4.html), NOAA Air Resources Laboratory, Silver Spring, MD, USA (last access: January 2010) 2003.

Draxler, R., Stunder, B., Rolph, G., et al.: HYSPLIT4 user's guide, Version 4.9, http://ready.arl.noaa.gov/HYSPLIT.php (last access: January 2010), 2009.

Drewnick, F., Hings, S. S., DeCarlo, P., et al.: A new time-of-flight aerosol mass spectrometer (TOF-AMS)-Instrument description and first field deployment, Aerosol. Sci. Tech., 39, 637-658, 2005.

Garland, R. M., Schmid, O., Nowak, A., et al.: Aerosol optical properties observed during Campaign of Air Quality Research in Beijing 2006 (CAREBeijing-2006): Characteristic differences between the inflow and outflow of Beijing city air, J. Geophys. Res., 114, D00G04, doi:10.1029/2008JD010780, 2009.

Guo, J. P., Zhang, X. Y., Che, H. Z., et al.: Correlation between PM concentrations and aerosol optical depth in eastern China, Atmos. Environ., 43, 5876-5886, 2009.

Han, S., Kondo, Y., Oshima, N., et al.: Temporal variations of elemental carbon in Beijing, J. Geophys. Res.-Atmos., 114, D23202, doi:10.1029/2009JD012027, 2009.

He, K. B., Yang, F. M., Ma, Y. L., et al.: The characteristics of $\mathrm{PM}_{2.5}$ in Beijing, China, Atmos. Environ., 35, 4959-4970, 2001.

He, L. Y., Hu, M., Huang, X. F., et al.: Measurement of emissions of fine particulate organic matter from Chinese cooking, Atmos. Environ., 38, 6557-6564, 2004.

He, L.-Y., Lin, Y., Huang, X.-F., Guo, S., Xue, L., Su, Q., Hu, M., Luan, S.-J., and Zhang, Y.-H.: Characterization of highresolution aerosol mass spectra of primary organic aerosol emissions from Chinese cooking and biomass burning, Atmos. Chem. Phys. Discuss., 10, 21237-21257, doi:10.5194/acpd-10-212372010, 2010.

Hennigan, C. J., Sullivan, A. P., Fountoukis, C. I., Nenes, A., Hecobian, A., Vargas, O., Peltier, R. E., Case Hanks, A. T., Huey, L. G., Lefer, B. L., Russell, A. G., and Weber, R. J.: On the volatility and production mechanisms of newly formed nitrate and water soluble organic aerosol in Mexico City, Atmos. Chem. Phys., 8, 3761-3768, doi:10.5194/acp-8-3761-2008, 2008

Huang, X. F., He, L. Y., Hu, M., and Zhang, Y. H.: Annual variation of particulate organic compounds in $\mathrm{PM}_{2.5}$ in the urban atmosphere of Beijing, Atmos. Environ., 40, 2449-2458, 2006.

Huffman, J. A., Docherty, K. S., Aiken, A. C., Cubison, M. J., Ulbrich, I. M., DeCarlo, P. F., Sueper, D., Jayne, J. T., Worsnop, D. R., Ziemann, P. J., and Jimenez, J. L.: Chemically-resolved aerosol volatility measurements from two megacity field studies, Atmos. Chem. Phys., 9, 7161-7182, doi:10.5194/acp-9-71612009, 2009.

Jayne, J. T., Leard, D. C., Zhang, X. F., et al.: Development of an aerosol mass spectrometer for size and composition analysis of submicron particles, Aerosol. Sci. Tech., 33, 49-70, 2000.

Jia, Y. T., Rahn, K. A., He, K. B., et al.: A novel technique for quantifying the regional component of urban aerosol solely from its sawtooth cycles, J. Geophys. Res.-Atmos., 113, D21309, doi:10.1029/2008JD010389, 2008.

Jimenez, J. L., Canagaratna, M. R., Donahue, N. M., et al.: Evolu- tion of organic aerosols in the atmosphere, Science, 326, 15251529, 2009.

Jimenez, J. L., Jayne, J. T., Shi, Q., et al.: Ambient aerosol sampling using the Aerodyne Aerosol Mass Spectrometer, J. Geophys. Res.-Atmos., 108, 8425, doi:10.1029/2001JD001213, 2003.

Jung, J., Lee, H., Kim, Y. J., et al.: Optical properties of atmospheric aerosols obtained by in situ and remote measurements during 2006 Campaign of Air Quality Research in Beijing (CAREBeijing-2006), J. Geophys. Res., 114, D00G02, doi:10.1029/2008JD010337, 2009.

Lanz, V. A., Alfarra, M. R., Baltensperger, U., Buchmann, B., Hueglin, C., and Prvt, A. S. H.: Source apportionment of submicron organic aerosols at an urban site by factor analytical modelling of aerosol mass spectra, Atmos. Chem. Phys., 7, 15031522, doi:10.5194/acp-7-1503-2007, 2007.

Lin, P., Hu, M., Deng, Z., et al.: Seasonal and diurnal variations of organic carbon in $\mathrm{PM}_{2.5}$ in Beijing and the estimation of secondary organic carbon, J. Geophys. Res.-Atmos., 114, D00G11, doi:10.1029/2008JD010902, 2009.

Liu, P. S. K., Deng, R., Smith, K. A., et al.: Transmission efficiency of an aerodynamic focusing lens system: comparison of model calculations and laboratory measurements for the Aerodyne Aerosol Mass Spectrometer, Aerosol. Sci. Tech., 41, 721733, 2006.

Matsui, H., Koike, M., Kondo, Y., et al.: Spatial and temporal variations of aerosols around Beijing in summer 2006: Model evaluation and source apportionment, J. Geophys. Res., 114, D00G13, doi:10.1029/2008JD010906, 2009.

Michaels, R. A. and Kleinman, M. T.: Incidence and apparent health significance of brief airborne particle excursions, Aerosol. Sci. Tech., 32, 93-105, 2000.

Mijling, B., van der A, R. J., Boersma, K. F., et al.: Reductions of $\mathrm{NO}_{2}$ detected from space during the 2008 Beijing Olympic Games, Geophys. Res. Lett., 36, L13801, doi:10.1029/2009GL038943, 2009.

Mohr, C., Huffman, J. A., Cubison, M. J., et al.: Characterization of Primary Organic Aerosol Emissions from Meat Cooking, Trash Burning, and Motor Vehicles with High-Resolution Aerosol Mass Spectrometry and Comparison with Ambient and Chamber Observations, Environ. Sci. Technol., 43, 2443-2449, 2009.

Ng, N. L., Canagaratna, M. R., Zhang, Q., Jimenez, J. L., Tian, J., Ulbrich, I. M., Kroll, J. H., Docherty, K. S., Chhabra, P. S., Bahreini, R., Murphy, S. M., Seinfeld, J. H., Hildebrandt, L., Donahue, N. M., DeCarlo, P. F., Lanz, V. A., Prévôt, A. S. H., Dinar, E., Rudich, Y., and Worsnop, D. R.: Organic aerosol components observed in Northern Hemispheric datasets from Aerosol Mass Spectrometry, Atmos. Chem. Phys., 10, 46254641, doi:10.5194/acp-10-4625-2010, 2010.

Paatero, P. and Hopke, P. K.: Discarding or downweighting highnoise variables in factor analytic models, Anal. Chim. Acta, 490, 277-289, 2003.

Paatero, P. and Tapper, U.: Positive Matrix Factorization-a Nonnegative Factor Model with Optimal Utilization of Error-Estimates of Data Values, Environmetrics, 5, 111-126, 1994.

Salcedo, D., Onasch, T. B., Dzepina, K., Canagaratna, M. R., Zhang, Q., Huffman, J. A., DeCarlo, P. F., Jayne, J. T., Mortimer, P., Worsnop, D. R., Kolb, C. E., Johnson, K. S., Zuberi, B., Marr, L. C., Volkamer, R., Molina, L. T., Molina, M. J., Car- 
denas, B., Bernabé, R. M., Márquez, C., Gaffney, J. S., Marley, N. A., Laskin, A., Shutthanandan, V., Xie, Y., Brune, W., Lesher, R., Shirley, T., and Jimenez, J. L.: Characterization of ambient aerosols in Mexico City during the MCMA-2003 campaign with Aerosol Mass Spectrometry: results from the CENICA Supersite, Atmos. Chem. Phys., 6, 925-946, doi:10.5194/acp-6-9252006, 2006.

Schwartz, J., Laden, F., and Zanobetti, A.: The concentrationresponse relation between $\mathrm{PM}_{2.5}$ and daily deaths, Environ. Health Persp., 110, 1025-1029, 2002.

Song, Y., Zhang, Y. H., Xie, S. D., et al.: Source apportionment of $\mathrm{PM}_{2.5}$ in Beijing by positive matrix factorization, Atmos. Environ., 40, 1526-1537, 2006.

Stone, R.: China's environmental challenges: Beijing's marathon run to clean foul air nears finish line, Science, 321, 636-637, 2008.

Streets, D. G., Fu, J. S., Jang, C. J., et al.: Air quality during the 2008 Beijing Olympic Games, Atmos. Environ., 41, 480-492, 2007.

Sun, J. Y., Zhang, Q., Canagaratna, M. R., et al.: Highly time- and size-resolved characterization of submicron aerosol particles in Beijing using an Aerodyne Aerosol Mass Spectrometer, Atmos. Environ., 44, 131-140, 2010.

Sun, Y., Zhang, Q., Macdonald, A. M., Hayden, K., Li, S. M., Liggio, J., Liu, P. S. K., Anlauf, K. G., Leaitch, W. R., Steffen, A., Cubison, M., Worsnop, D. R., van Donkelaar, A., and Martin, R. V.: Size-resolved aerosol chemistry on Whistler Mountain, Canada with a high-resolution aerosol mass spectrometer during INTEX-B, Atmos. Chem. Phys., 9, 3095-3111, doi:10.5194/acp9-3095-2009, 2009.

Takegawa, N., Miyakawa, T., Kuwata, M., et al.: Variability of submicron aerosol observed at a rural site in Beijing in the summer of 2006, J. Geophys. Res.-Atmos., 114, D00G05, doi:10.1029/2008JD010857, 2009.

Takegawa, N., Miyakawa, T., Kuwata, M., et al.: Variability of submicron aerosol observed at a rural site in Beijing in the summer of 2006, J. Geophys. Res., 114, D00G05, doi:10.1029/2008JD010857, 2009.

Ulbrich, I. M., Canagaratna, M. R., Zhang, Q., Worsnop, D. R., and Jimenez, J. L.: Interpretation of organic components from Positive Matrix Factorization of aerosol mass spectrometric data, Atmos. Chem. Phys., 9, 2891-2918, doi:10.5194/acp-9-2891-2009, 2009.

van Pinxteren, D., Bruggemann, E., Gnauk, T., et al.: Sizeand time-resolved chemical particle characterization during CAREBeijing-2006: Different pollution regimes and diurnal profiles, J. Geophys. Res., 114, D00G09, doi:10.1029/2008JD010890, 2009.
Wang, S., Zhao, M., Xing, J., et al.: Quantifying the Air Pollutants Emission Reduction during the 2008 Olympic Games in Beijing, Environ. Sci. Technol., 44, 2490-2496, 2010.

Witte, J. C., Schoeberl, M. R., Douglass, A. R., et al.: Satellite observations of changes in air quality during the 2008 Beijing Olympics and Paralympics, Geophys. Res. Lett., 36, L17803, doi:10.1029/2009GL039236, 2009.

Yue, D., Hu, M., Wu, Z., et al.: Characteristics of aerosol size distributions and new particle formation in the summer in Beijing, J. Geophys. Res., 114, D00G12, doi:10.1029/2008JD010894, 2009.

Zhang, Q., Canagaratna, M. R., Jayne, J. T., et al.: Time- and sizeresolved chemical composition of submicron particles in Pittsburgh: Implications for aerosol sources and processes, J. Geophys. Res.-Atmos., 110, D07S09, doi:10.1029/2004JD004649, 2005 b.

Zhang, Q., Jimenez, J. L., Canagaratna, M. R., et al.: Ubiquity and dominance of oxygenated species in organic aerosols in anthropogenically-influenced Northern Hemisphere midlatitudes, Geophys. Res. Lett., 34, L13801, doi:10.1029/2007GL029979, 2007.

Zhang, Q., Streets, D. G., Carmichael, G. R., He, K. B., Huo, H., Kannari, A., Klimont, Z., Park, I. S., Reddy, S., Fu, J. S., Chen, D., Duan, L., Lei, Y., Wang, L. T., and Yao, Z. L.: Asian emissions in 2006 for the NASA INTEX-B mission, Atmos. Chem. Phys., 9, 5131-5153, doi:10.5194/acp-9-5131-2009, 2009.

Zhang, Q., Worsnop, D. R., Canagaratna, M. R., and Jimenez, J. L.: Hydrocarbon-like and oxygenated organic aerosols in Pittsburgh: insights into sources and processes of organic aerosols, Atmos. Chem. Phys., 5, 3289-3311, doi:10.5194/acp-5-32892005, 2005c.

Zhang, Q., Zhang, J., and Xue, H.: The challenge of improving visibility in Beijing, Atmos. Chem. Phys. Discuss., 10, 61996218, doi:10.5194/acpd-10-6199-2010, 2010.

Zhao, X. J., Zhang, X. L., Xu, X. F., et al.: Seasonal and diurnal variations of ambient $\mathrm{PM}_{2.5}$ concentration in urban and rural environments in Beijing, Atmos. Environ., 43, 2893-2900, 2009.

Zhao., Y. L, Hu, M., Slanina, S., and Zhang, Y. H.: Chemical compositions of fine particulate organic matter emitted from Chinese cooking, Environ. Sci. Technol., 41, 99-105, 2007.

Zheng, J., Zhang, R., Fortner, E. C., Volkamer, R. M., Molina, L., Aiken, A. C., Jimenez, J. L., Gaeggeler, K., Dommen, J., Dusanter, S., Stevens, P. S., and Tie, X.: Measurements of $\mathrm{HNO}_{3}$ and $\mathrm{N}_{2} \mathrm{O}_{5}$ using ion drift-chemical ionization mass spectrometry during the MILAGRO/MCMA-2006 campaign, Atmos. Chem. Phys., 8, 6823-6838, doi:10.5194/acp-8-6823-2008, 2008. 